\title{
Między tradycjq a nowoczesnościq, pod red. K. Rędzińskiego, Wydawnictwo im. Stanisława Podobińskiego Akademii im. Jana Dhugosza w Częstochowie, Częstochowa 2007, ss. 235
}

Z cyklu „Prace naukowe Akademii im. Jana Długosza w Częstochowie. Pedagogika Tom XVI" w roku 2007 ukazała się publikacja zbiorowa Między nowoczesnościa a tradycją. Zawiera ona piętnaście artykułów, które dotyczą różnorodnych aspektów nauczania i wychowania. Redaktorem tomu jest Kazimierz Rędziński.

Tematyka tomu została podzielona na trzy bloki, będące jednocześnie trzema perspektywami badawczymi. Stąd w pierwszej części znalazły się opracowania dotyczące teorii wychowania. Pierwsze z nich, autorstwa Stanisława Cz. Michałowskiego, nosi tytuł: W kręgu sporu o podstawy wspótczesnej edukacji, czyli między kierunkami rozwoju cywilizacji a kontekstem wspótczesnego wychowania. Zdaniem autora zachodzi ścisła korelacja pomiędzy wychowaniem jednostki a losami społeczeństwa, w którym ona egzystuje. W tekście tym ponadto autor podaje, że wartość człowieka leźy w jego osobowości, a nie w tym, co się posiada. Krytycznie też odnosi się do współczesnych modeli wychowawczych, stąd odpowiedź na pytanie: Jak wychowywać? tylko pozornie może się wydawać prosta. Kolejny autor tomu, Janusz Czerny, opisuje kontrowersyjne zjawisko wychowawczego ,autyzmu”. Sam termin ,autyzm” posłużył jedynie jako ilustracja, ułatwił autorowi dokonania przeglądu pewnych stanowisk i poglądów na temat wychowania. Jolanta Wilsz z kolei zajęła się komunikowaniem się interpersonalnym $\mathrm{w}$ procesie nauczania, którą to umiejętność winni posiąść zarówno uczniowie, jak i nauczyciele. O potrzebach przeciwdziałania procesom marginalizacji transformacyjnej pisze natomiast Iwona Wagner. Autorka podaje skutki nierówności społecznych oraz przedstawia rolę i zadania pedagogiki społecznej, która może owej marginalizacji przeciwdziałać. Ostatni artykuł tej części prezentowanej pracy to Odrębność narodowa i regionalna na tle procesów globalizacji Adrianny Sarnat. Zdaniem autorki, globalizacja, współczesne słowo „fetysz” niejednoznacznie oceniane $\mathrm{z}$ całą pewnością przyczyniła się do wzmocnienia poczucia odrębności narodowej i regionalnej.

Drugą część publikacji „Między tradycją a nowoczesnością”, część badawczą, otwiera studium socjologiczne Józefa Baniaka na temat moralności seksualnej młodzieży gimnazjalnej, która została ukazana na tle kryzysu tożsamości osobowej. Autor wykazał, że na postawy seksualne młodzieży największy wpływ mają wychowanie religijne i kryzys tożsamości osobowej. Oba te czynniki mogą wpływać na intensyfikację bądź zahamowanie konkretnych zachowań seksualnych. Artykuł Danuty Boreckiej-Biernat nosi tytuł: Agresywna strategia radzenia sobie mlodzieży $w$ spolecznych sytuacjach trudnych a poczucie umiejscowienia kontroli oraz jej uzależnienie od postaw rodzicielskich. Sama autorka uzasadniła potrzebę zajęcia się tym tematem w taki oto sposób: „sytuacje trudne nie są w życiu człowieka czymś wyjątkowym. Przeciwnie, towarzyszą człowiekowi od wczesnego dzieciństwa, nie jest więc sprawą obojętną wiedza na temat działań podejmowanych przez jednostkę w celu radzenia sobie w sytuacjach trudnych [...]" (s. 117). Kolejna współautorka tomu to Iwona M. Strachanowska. Zaprezentowała ona model edukacji 
międzykulturowej na Uniwersytecie Kazimierza Wielkiego w Bydgoszczy. Lidia Włodarska-Zoła przyjrzała się natomiast kształceniu na uczelniach technicznych na kierunku zarządzanie w kontekście przemian w polskim systemie gospodarczym. Winno ono, według autorki, być zdeterminowane zarówno polskimi tradycjami, modelami kształcenia w krajach Europy Zachodniej, jak i wymaganiami stawianymi przez gospodarkę. O systemie wartości osób współuzależnionych traktuje praca Izabeli Zimoch. Metodą, jaką się posłużyła autorka była ankieta, zapewniającą badanym maksymalną anonimowość, a tym samym większą ich szczerość. Część „badawczą" tomu kończą badania Sławomira Sztaby na temat zróżnicowania narodowego i etnicznego sierot w domach dziecka w województwie podkarpackim. Wyjaśniając kwestię owego zróżnicowania autor przedstawił genezę badanego regionu oraz strukturę narodowościową jego mieszkańców, szczegółowo skupiając się na mniejszościach narodowych i etnicznych.

Dział „Historia” składa się z trzech artykułów. Koncentrują się one wokół tematyki wychowania i edukacji żydowskiej. Pierwszym z nich jest praca Kazimierza Rędzińskiego na temat oświaty i szkolnictwa żydowskiego w Kaliszu w latach 1867-1914. Naczelnym wnioskiem autora jest stwierdzenie, że liczba szkół żydowskich w Kaliszu na przełomie XIX i XX wieku była niedostateczna, a kierunek i treści nauczania w istniejących dyktowane były jedynie polityką zaborcy, która nie uwzględniała w jakikolwiek sposób potrzeb ludności żydowskiej. Tematyka żydowska poruszona także została w kolejnym artykule autorstwa Mirosława Łapota. Pisze on bowiem o żydowskim ideale wychowania po pierwszej wojnie światowej. Zakładał on zerwanie ze stereotypem Żyda - handlarza w tradycyjnym chałacie, $z$ brodą, biernie znoszącego prześladowania w oczekiwaniu na przyjście mesjasza. Nowoczesny Żyd miał być świadomy swej tożsamości narodowej, miał być wykształconym człowiekiem czynu, przygotowanym praktycznie do życia, w przyszłości tworzącego nowoczesne państwo Izrael, szanującym religię i obyczajowość, ale nie traktujący Tory i Talmudu jako jedynych wyznaczników postępowania. O wychowaniu żydowskich dziewcząt traktuje Agnieszka Kaczyńska. Przedstawia ona bowiem w swoim artykule Prywatne Żeńskie Gimnazjum Humanistyczne Żydowskiego Towarzystwa Szkoły Ludowej i Średniej we Lwowie. Głównym celem wychowawczym szkoły było ukształtowanie uczennic na jednostki samodzielne, odpowiedzialne i uspołecznione. Blok historyczny zamyka recenzja książki Andrzeja Kozery Edukacja w polskiej myśli politycznej (1918-1939). Jej autorem jest Jerzy Zdański. Krytyk docenił popularyzatorski charakter książki i jej unikatowe ujęcie tematu.

Reasumując, publikacja Między tradycjq a nowoczesnościq zasługuje na uwagę czytelnika. Bo po pierwsze, zakres tematyki w niej podjętej jest adekwatny do tytułu, po drugie zaś, stanowi ona forum wypowiedzi badaczy z różnych ośrodków badawczych, a jak zaznaczył we wstępie redaktor tomu, „autorzy [ci] stosują różnorodne metodologie badawcze: stricte pedagogiczne, psychologiczne, socjologiczne oraz historyczne. Odmienne perspektywy badawcze umożliwiły wieloaspektowe spojrzenie na problemy edukacji i wychowania" (s. 7).

Edyta Gtowacka-Sobiech 